\title{
PUPUK ORGANIK CAIR DARI LIMBAH PERTANIAN DAPAT MENINGKATKAN PERTUMBUHAN DAN PRODUKSI TANAMAN KEDELAI EDAMAME
}

\author{
LIQUID ORGANIC FERTILIZER FROM AGRICULTURAL WASTE CAN INCREASE THE \\ GROWTH AND PRODUCTION OF EDAMAME \\ SOYBEAN PLANT
}

Sri Wahyuni dan Indratin

Balai Penelitian Lingkungan Pertanian, Jl. Raya Jakenan Jaken KM 05

Jakenan Pati 59182

e-mail:swahuni@gmail.com

* semua author kontributor utama

Diterima: 25 Nopember 2020, Direvisi: 30 Nopember 2020, Disetujui: 11 Desember 2020

\begin{abstract}
ABSTRAK
Kedelai edamame merupakan kedelai yang banyak nutrisinya, bagus untuk kesehatan. Masyarakat mulai mengkonsumsi kedelai sejak dari dulu dan mempunyai nilai ekonomi yang tinggi. Dalam budidaya tanaman, tentunya membutuhkan pupuk sebagai nutrisi. Kesulitan dalam mendapatkan pupuk, limbah-limbah pertanian yang ada di sekitar kita bisa digunakan sebagai solusi pupuk bagi tanaman. Untuk meningkatkan produksi kedelai, salah satu cara dengan memanfaatkan pupuk organik cair (POC). POC dapat dimanfaatkan untuk peningkatan produksi kedelai. Pupuk organik ini sebagai salah satu solusi menggantikan fungsi tanaman kacang-kacangan dalam asupan hara. Penelitian menggunakan rancangan acak lengkap (RAL) dengan 3 perlakuan: 1) POC A (urin sapi, sludge, abu sekam, air, pelepah pisang, mikroba); 2) POC B (urin sapi, sludge, abu sekam, air); 3) POC komersial (kontrol) dan diulangan 6 kali. Penelitian ini bertujuan untuk mendapatkan informasi pertumbuhan dan peningkatan produksi tanaman kedelai dengan memanfaatkan pupuk organik cair. Tanaman disemprot secara merata dipermukaan daun setiap 1 minggu sekali. Penelitian dilaksanakan di Rumah Kaca Kebun Percobaan Jakenan skala pot dari bulan Juli September 2020. Tanaman yang digunakan adalah kedelai edamame. Pupuk dasar menggunakan pupuk organik kotoran sapi sebanyak 5 ton ha $^{-1}$ yang aplikasinya digunakan untuk menutup benih kedelai saat tanam. Hasil penelitian menunjukkan bahwa penggunaan pupuk organik cair yang diperkaya mikroba dapat meningkatkan tinggi tanaman, jumlah polong, berat biomassa, dan berat polong. Pupuk organik cair merupakan salah satu solusi pemupukan untuk tanaman kedelai/kacangkacangan.
\end{abstract}

Kata Kunci : pupuk organik cair, mikroba, peningkatan produksi tanaman kedelai.

\begin{abstract}
Edamame soybean is highly nutritious and good for health. People started consuming soy a long time ago and it has high economic value. In crop cultivation, fertilizers are surely needed as plant nutrition. The difficulty in getting fertilizers can be solved by using agricultural wastes that are around us to be used as fertilizer solutions for plants. One way to increase soybean production is by utilizing liquid organic fertilizer (LOF). LOF can be used to increase soybean production. This organic fertilizer is a solution to replace the function of legumes in nutrient intake. The study used a completely randomized design (CRD) with 3 treatments; 1) LOF A (cow urine, sludge, husk
\end{abstract}


ash, water, banana bunch, microbes); 2) LOF B (cow urine, sludge, husk ash, water); 3) LOF market and repeated 6 times. This study aims to obtain detailed information on the growth and increased in soybeans production by utilizing liquid organic fertilizer. Plants are sprayed evenly on the surface of the leaves every 1 week. The research was carried out in the Jakenan Experimental Garden Greenhouse from July - September 2020. The plant is used as edamame beans. The basic fertilizer used organic cow manure as much as 5 tons ha-1 which its application is used to cover soybean seeds when planting. The results showed that the use of liquid organic fertilizer enriched with microbes increased plant height, pod number, stover weight, and pod weight. Liquid organic fertilizer is one of the fertilization solutions for soybeans/beans.

Keywords: Liquid organic fertilizer, microbes, increased soybean production

\section{PENDAHULUAN}

Kedelai edamame adalah salah satu tanaman kacang-kacangan dan merupakan sumber protein nabati yang tinggi. Kedelai sangat diminati masyarakat saat ini. Begitu besarnya kontribusi kedelai dalam hal penyediaan bahan pangan bergizi bagi manusia sehingga kedelai merupakan salah satu pangan strategis setelah padi dan jagung. Biji kedelai mengandung fosfor, zat besi, kalsium, vitamin B dengan komposisi asam amino lengkap, sehingga potensial untuk pertumbuhan tubuh manusia (Fauzi dan Puspitawati, 2018).

Kebutuhan kedelai nasional sangat tinggi pada tahun 2015 mencapai 963.183 ton dari kedelai lokal, dan 2.206.444 ton dari kedelai impor atau setara dengan $30 \%$ kedelai lokal $70 \%$ kedelai impor (Tegoeh, 2016).

Kekhawatiran terhadap membanjirnya kedelai impor telah mematikan usahatani kedelai nasional. Upaya untuk meningkatkan produksi kedelai dan mencapai swasembada kedelai dirintis sebelum dan pada era reformasi, antara lain melalui program Gema Palagung (Gerakan Mandiri Padi, Kedelai, Jagung). Upaya peningkatan produksi kedelai harus terus diatasi, karena kedelai adalah salah satu komoditas pangan yang cukup strategis. (Poniman et al, 2015)

Kedelai mempunyai prospek bisnis yang bagus mengingat nilai ekonominya yang tinggi. Kebutuhan kedelai dalam negeri $70 \%$ dipasok dari kedelai impor dan $30 \%$ domestik. Produksi kedelai di Indonesia masih rendah, rata-rata produksi kedelai secara Nasional mencapai 1,57 ton/ha, di Jawa Tengah 1,8 ton/ha, Grobogan 2,3 ton/ha (Pratomo, 2016).

Dalam budidaya tanaman, tentu tidak lepas dari penggunaan pupuk. Penggunaan pupuk anorganik secara terus menerus dengan takaran tinggi dapat menstimulasi penurunan produktivitas tanah sawah baik fisik, kimia, dan hayati. Untuk mengurangi penggunaan pupuk anorganik, pupuk organik cair adalah salah satu solusi untuk budidaya tanaman.

Kebutuhan pupuk organik alami dari tahun ke tahun semakin meningkat akibat semakin mahal dan langkanya pupuk anorganik di pasaran, juga meningkatnya permintaan produk organik yang menghindari penggunaan pupuk kimia, yang ditengarai berdampak buruk bagi kesehatan karena terdapat unsur ikutan logam berat. Terobosan baru pun mulai dilakukan untuk mendapatkan pupuk organik cair yang berkualitas.

Perbaikan lingkungan untuk pertumbuhan tanaman dapat dilakukan melalui pemberian pupuk organik, terutama di lahan sawah tadah hujan. Sawah tadah hujan umumnya mempunyai tingkat kesuburan tanah yang redah. Jika tanah tidak cukup dalam menyediakan 
unsur hara bagi tanaman maka pemberian pupuk perlu dilakukan. Salah satu faktor yang menunjang pertumbuhan tanaman dan berproduksi secara optimal adalah ketersediaan unsur hara yang cukup dalam tanah (Ruhnayat, 2007).

Tanaman kedelai mempunyai bintil akar, yang bisa melakukan fiksasi Nitrogen (N). Penambahan mikroba dalam pupuk organik cair, diharapkan mampu meningkatkan kesuburan tanaman. Mikroba penambat $\mathrm{N}$ secara enzimatis menggabungkan $\mathrm{N}$ atmosfer dengan unsur-unsur lain untuk membentuk senyawa N-organik dalam sel hidup. Dalam bentuk organik ini kemudian $\mathrm{N}$ dilepaskan ke dalam bentuk terlambat, tersedia bagi tanaman baik secara langsung maupun melalui aktifitas jasad mikro. Penambatan $\mathrm{N}$ non-simbiotik dapat juga terjadi di atmosfer akibat halilintar dan nitrogen oksida yang terbentuk oleh pembakaran mesin dapat mengalami fotokimia dan nitrogen yang terikat dengan cara ini jatuh ke tanah bersama air hujan (Wahyuni, et al., 2018).

Limbah pertanian seperti urin sapi, pelepah pisang, abu sekam, slugde dapat digunakan sebagai bahan untuk pembuatan pupuk organik cair (POC). Salah satu pupuk organik cair Balingtan (Balai Lingkungan Pertanian, Kementan), ditambahkan dengan Bacillus aryabhattai. Tanaman yang diinokulasi $B$. aryabhattai lebih tahan terhadap kekeringan dan mampu meningkatkan produktivitas. $B$. aryabhattai meningkatkan pertumbuhan kedelai dan tanaman gandum dengan meningkatkan mobilisasi dan fortifikasi bio seng (Ramesh, 2014).

Penambahan bakteri yang ada dalam tanah, dapat meningkatkan meningkatkan populasi mikroba tanah, sehingga dapat meningkatkan aktivitas mikroorganisme tanah. Jumlah populasi rhizobium dalam tanah banyak secara tidak langsung berpengaruh terhadap penyerapan hara dalam tanah, dan perakaran tanamanpun akan lebih panjang (Wahyuni, et al., 2018).

Pupuk organik cair ini menggunakan limbah yang secara langsung mengurangi pencemaran, dan formulasi bahan ini mengandung unsur hara yang dibutuhkan oleh tanaman, dan biaya produksinya lebih murah dibandingkan pupuk organik cair yang ada di pasaran.

Penggunaan pupuk organik di lahan sawah mulai berkurang dengan tingginya ketergantungan petani pada pupuk anorganik berkadar hara tinggi dan frekuensi tanam yang intensif (Suhartatik et al., 2002). Kompos sebagai bahan pembawa (carrier) mengandung karbon sebagai sumber energi aktivitas dan metabolisme bakteri tanah untuk merombak bahan organik menjadi tersedia untuk tanaman padi. Hal tersebut sesuai dengan pendapat (Noviani, et al., 2018)

Dalam pertumbuhan tanaman, peran pupuk $\mathrm{N}$ sangat diperlukan untuk proses fotosintesa tanaman. Nitrogen yang berlimpah dapat meningkatkan pertumbuhan dengan cepat terutama pada batang, daun-daun menjadi hijau gelap dan tanaman menjadi sekulen sehingga mudah hama dan penyakit (Novriani, 2011). Pupuk $\mathrm{N}$ adalah bagian yang tidak dipisahkan dari molekul klorofil dan kerenanya pemberian $\mathrm{N}$ dalam jumlah cukup akan meningkatkan pertumbuhan vegetatif tanaman.

Pupuk kandang (pukan) sebagai sumber hara makro, mikro, dan asamasam organik, berperan sebagai bahan pembenah tanah untuk memperbaiki kesuburan fisik, kimia, dan biologi tanah dalam jangka panjang. Aplikasi pukan/ pupuk organik bukan sebagai pengganti pupuk anorganik, namun sebagai komplemen. Aplikasi pupuk organik sebaiknya secara terpadu dengan pupuk anorganik, untuk meningkatkan produk- 
tivitas tanah dan tanaman secara berkelanjutan (Siswanto et al., 2015).

Kegiatan penelitian dilaksanakan dengan tujuan mendapatkan informasi pertumbuhan dan peningkatan produksi tanaman kedelai dengan memanfaatkan pupuk organik cair.

\section{METODE}

Penelitian ini dilaksanakan pada bulan Juli - September 2020 di Rumah Kaca Kebun Percobaan Jakenan (Pati) pada skala pot diameter $25 \mathrm{~cm}$. Penelitian menggunakan rancangan acak lengkap (RAL) dengan 3 perlakuan dan 6 ulangan. Adapun perlakuannya adalah: 1) POC A (urin sapi, sludge, abu sekam, air, pelepah pisang, B.aryabhattai); 2) POC B (urin sapi, sludge, abu sekam, air); 3) POC komersial/greentonik (kontrol)

Tanah yang digunakan untuk mengisi pot sebanyak $9 \mathrm{~kg}$. Tanaman yang digunakan adalah kedelai Edamame 2 biji /lubang/pot. Pupuk yang digunakan adalah pupuk kotoran sapi sebanyak $5 \mathrm{t} \mathrm{ha} \mathrm{ha}^{-1}$. Aplikasi pupuk kandang digunakan untuk penutup benih kedelai Edamame dan diratakan di sekitar benih. Pupuk organik cair, diaplikasikan setiap minggu sekali dengan cara disemprotkan pada permukaan daun secara merata.

Parameter yang diamati adalah tinggi tanaman, jumlah polong, berat biomassa dan berat polong. Pencegahan serangan hama penyakit tanaman menggunakan pestisida nabati dari serai wangi disemprotkan pada permukaan daun
1-2 minggu sekali sampai 2 minggu menjelang panen

Data hasil pengamatan dilakukan analisis lapang diolah menggunakan SAS Institute (2004).

\section{HASIL DAN PEMBAHASAN Tinggi Tanaman}

Tinggi tanaman pada berbagai perlakuan menunjukkan perbedaan yang nyata. Perlakuan A penggunaan POC limbah pertanian (urin sapi, sludge, abu sekam, air, pelepah pisang, B.aryabhattai) memiliki tinggi tanaman tertinggi, dan diikuti perlakuan B (urin sapi, sludge, abu sekam, air), dan perlakuan C (POC komersial). Hal ini diduga pelepah pisang mempunyai manfaat untuk merangsang perkembangan mikrobiologi dalam tanah. Perlakuan POC yang diperkaya dengan $B$. aryabhattai, mempunyai kemampuan meningkatkan kesuburan tanaman sehingga tinggi tanaman akan meningkat. B. aryabhattai menghasilkan sejumlah besar asam absisat, sitokinin dan asam gibberelat yang berbeda dalam kultur (Park Yeon-Gyeong, 2017). Fungsi asam absisat adalah membantu tanaman dalam mengatasi tekanan pada lingkungan yang kurang baik. Sitokinin berperan dalam merangsang pembelahan sel dengan cepat serta merangsang pertumbuhan akar. Fungsi giberelin, memengaruhi pertumbuhan dan perkembangan akar, daun, bunga, dan bunga serta berperan dalam pemanjangan batang. Hal ini disajikan dalam Gambar 1. 


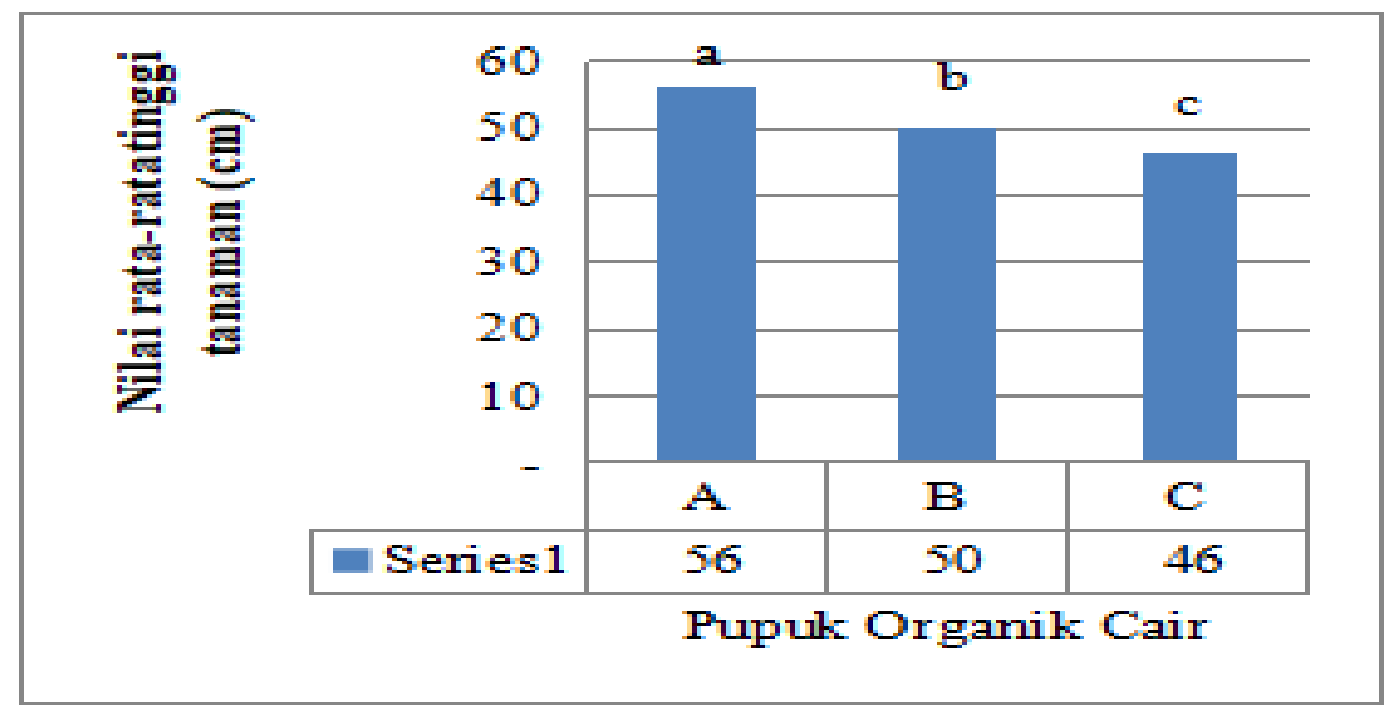

Gambar 1.

Nilai rata-rata tinggi tanaman kedelai dengan perlakuan pupuk organik cair

\section{Jumlah Polong}

Pada Gambar 2 menunjukkan bahwa jumlah polong pada perlakuan POC mempunyai perbedaan yang sangat nyata antar perlakuan. Jumlah polong tertinggi pada perlakuan POC A (limbah pertanian yang diperkaya $B$. aryabhattai) mempunya jumlah polong per tanaman rata-rata 60 buah untuk POC B (limbah pertanian) jumlah polong pertanaman rata-rata 54 buah, sedangkan aplikasi POC C (komersial) jumlah polong rata-rata per tanaman sebanyak 50 buah. Hal ini diduga POC yang diperkaya mikroba mempunyai kemampuan untuk mencegah serangan hama dan penyakit tanaman, sehingga tanaman bisa tumbuh subur dan mampu berproduksi dengan baik. POC limbah pertanian yang diperkaya $B$. aryabhattai mengandung nutrisi yang bisa dimanfaatkan oleh tanaman untuk pertumbuhannya. POC limbah pertanian yang diperkaya $B$. aryabhattai, sangat bagus diaplikasikan pada tanaman kacangkacangan. B. aryabhattai termasuk dalam bakteri penambat $\mathrm{N}$ simbiotik. Bakteri $\mathrm{N}$ simbiotik merupakan bakteri yang mampu melakukan fiksasi $\mathrm{N}$ dari udara.

Lalu Fauzan Walid dan Susylowati (2016) mengatakan, bahwa pengaruh perlakuan pupuk organik cair NASA menunjukkan perbedaan yang sangat nyata terhadap jumlah polong total per tanaman dengan konsentrasi POC NASA 4 mL L-1 air menunjukkan hasil tertinggi yaitu 31,42 


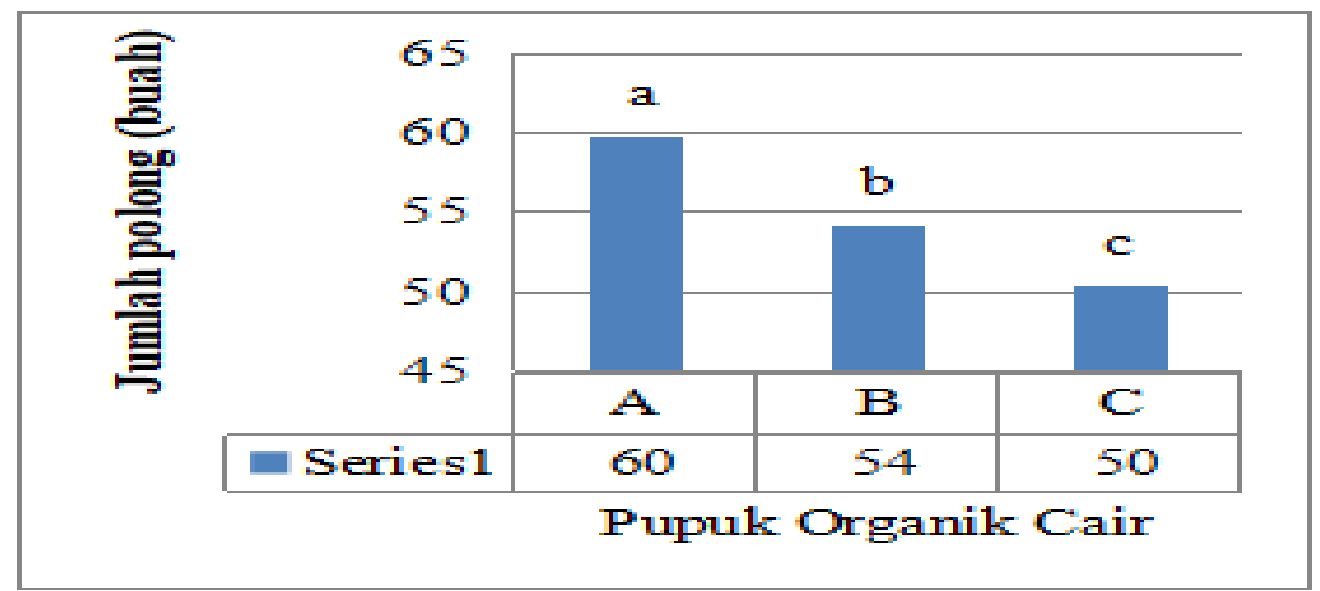

Gambar 2.

Nilai rata-rata jumlah polong dengan perlakuan pupuk organik cair

\section{Berat Biomassa Tanaman}

Berat biomassa pada berbagai perlakuan tidak menunjukkan perbedaan yang nyata. Semua pupuk organik cair baik untuk melakukan proses fotosintesa, dan menghasilkan biomas yang optimal juga. Perlakuan yang memiliki berat brangkasan dari yang tertinggi hingga terendah berturut turut pada perlakuan POC A (limbah pertanian yang diperkaya dengan Bacillus aryabhattai) > POC B (limbah pertanian) > POC C (komersial)

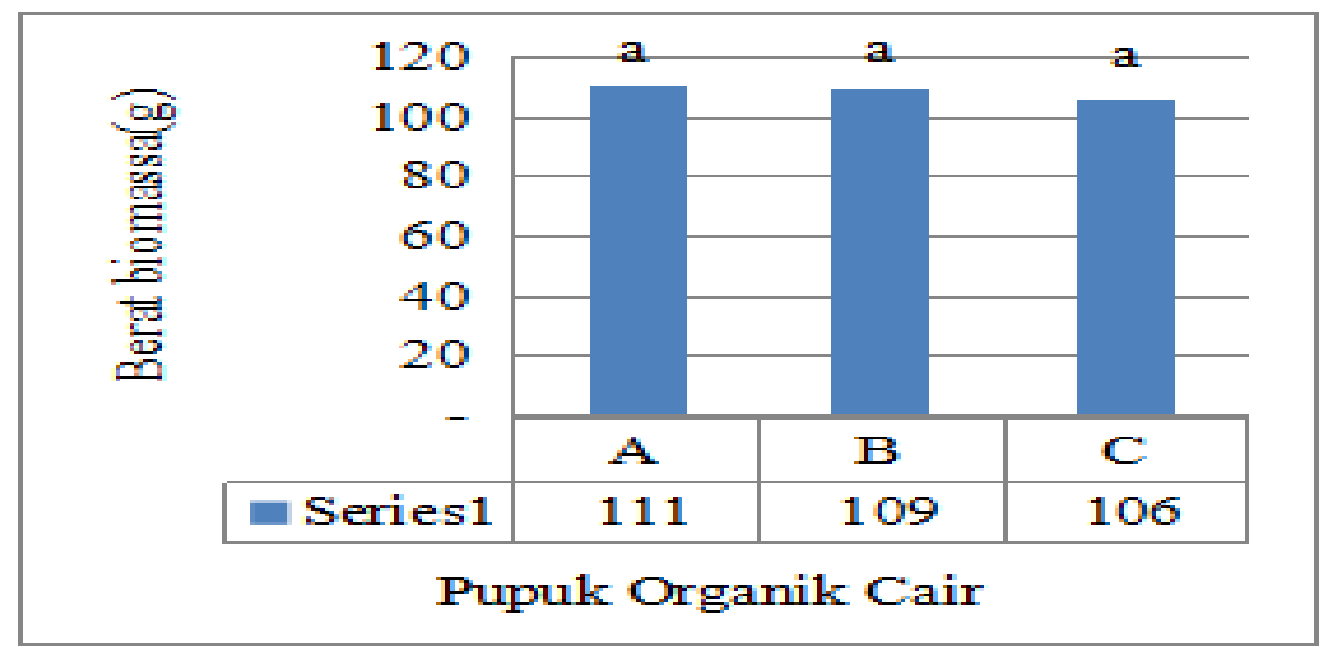

Gambar 3.

Nilai rata-rata berat biomassa dengan perlakuan pupuk organik cair

\section{Berat Polong}

Peningkatan produksi kedelai sangat didukung kandungan hara dalam tanah, sehingga sangat diperlukan pupuk kandang untuk meningkatkan produksi tanaman. Pemberian pupuk organik cair saja tanpa pemberian pupuk organik padat hasil belum bisa maksimal, dan sebaliknya dengan pemberian pupuk organik padat saja, kurang baik untuk peningkatan produksi tanaman. Dengan penambahan bakteri pupuk organik cair jadi lebih efektif dan dalam penyemprotan tertunya ada percikan baketri yang jatuh ke tanah, 
dan akan meningkatkan kesuburan lahan karena bakteri yang jatuh ke tanah akan merombak bahan organik yang ada didalam tanah menjadi tersedia untuk tanaman, produksi tanaman kedelai juga tinggi. Pupuk organik cair yang berasal dari limbah pertanian mampu mengimbangi pupuk organik yang ada dipasaran. Hal ini disajikan dalam Gambar 4.

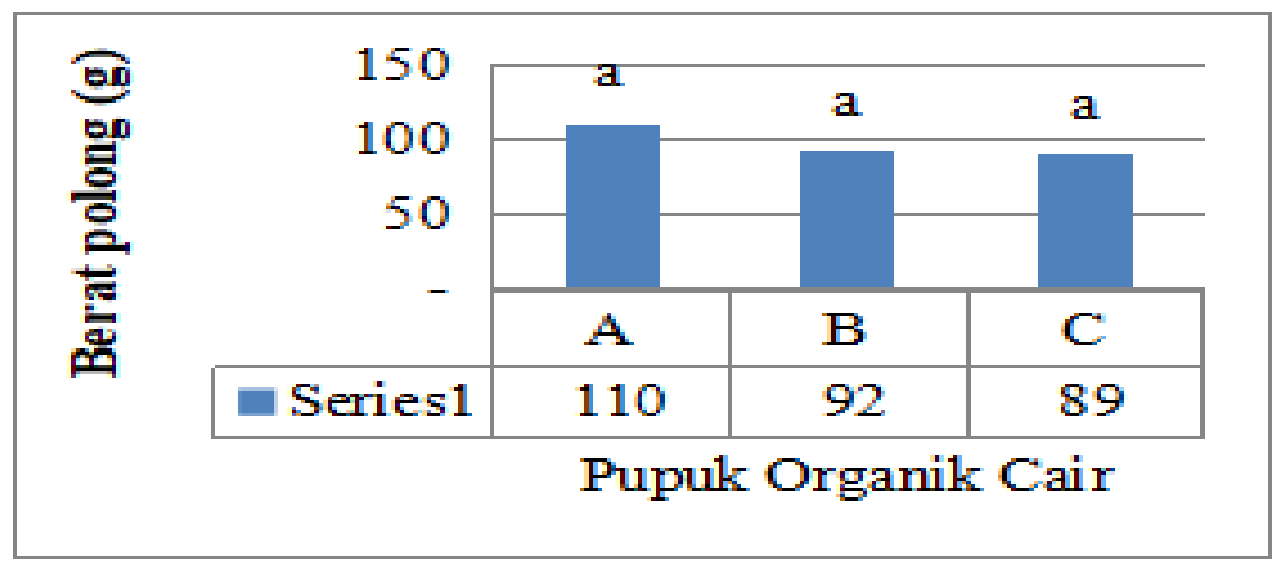

Gambar 4.

Nilai rata-rata jumlah polong dengan perlakuan pupuk organik cair

Hal serupa sesuai dengan penelitian Wahid dan Susilawati (2016), bahwa perlakuan pupuk organik cair NASA dengan konsentrasi $6 \quad \mathrm{~mL}^{-1}$ air memberikan hasil berat biji kering tertinggi 4,50 $\mathrm{Mg} \mathrm{ha}^{-1}$ tetapi berbeda tidak nyata dengan perlakuan konsentrasi $4 \mathrm{~mL}$ $\mathrm{L}^{-1}$ air (k2) dengan hasil biji kering 0,44 $\mathrm{Mg} \mathrm{ha}^{-1}$.

\section{SIMPULAN}

Pupuk organik cair dari limbah pertanian dengan komposisi urin sapi, sludge, abu sekam, air, pelepah pisang, yang diperkaya dengan Bacillus aryabhattai, mampu meningkatkan pertumbuhan tanaman dan produksi tanaman kedelai. Pupuk organik cair dari limbah pertanian juga merupakan solusi tepat untuk menggurangi pupuk kimia.

\section{SARAN}

Perlu dilakukan kajian lebih lanjut tentang penggunaan pupuk organik cair dari limbah pertanian yang bisa meningkatkan produksi di skala lapang. Perlu diuji cobakan juga untuk komoditas lainnya.

\section{UCAPAN TERIMA KASIH}

Ucapan terima kasih disampaikan kepada Balai Penelitian Lingkungan Pertanian yang telah memfasilitasi penelitian ini. Kepada Dr. E. S. Harsanti (Ka. Kelti EP3) yang telah mengijinkan kami untuk bereksperimen, Kepada bapak Karsono, mba Nourma, mas Soleh, mba Yunda, mba Nadia yang telah membantu kegiatan penelitian sampai selesai. 


\section{DAFTAR PUSTAKA}

Fauzi, A.R.dan M. D. Puspitawati, 2018. Budidaya tanaman kedelai ( glycine max 1.) Varietas burangrang pada lahan kering. J Bioindustri Vol. 1. No. 1.

Lalu Fauzan Walid dan Susylowati. 2016. Pengaruh konsentrasi pupuk organik cair (poc) terhadap pertumbuhan dan hasil beberapa varietas tanaman kedelai (Glycine Max (L.) Merill). J Ziraa'ah Volume 41 Nomor 1, Pebruari 2016 Halaman 84-96

Novriani. 2011. Peranan rhizobium dalam meningkatkan ketersediaan nitrogen bagi tanaman kedelai. Agronobis,Vol. 3, No. 5

Noviani, S. Slamet and A. Citraresmini, 2018. Kontribusi kompos jerami biochar dalam peningkatan ptersedia, jumlah populasi bpf dan hasil padi sawah, J. Ilmiah Aplikasi Isotop dan Radiasi, vol. 1, no. 14, pp. 47-57. 2018.

Poniman, E. Yulianingsih, Suryanto. 2015. Sumbangan pemikiran bagi Program Intensifikasi \& Ekstensifikasi Kedelai. 75 hal. Balai Penelitian Lingkungan Pertanian. Kementerian Pertanian. Penerbit PT Kanisius. Yogyakarta.

Pratomo. 2016. Analisis Kebutuhan Kedelai Jawa Tengah. Kajian Strategis Kedelai di Jawa Tengah. Surakarta.

Ramesh, R. \& Achari, G.A. 2014. Diver;sity, biocontrol, and plant growth promo;ting abilities of xylem residing bacteria from solanaceous crops. J International of Microbiology. Hal 1-14.

Ruhnayat A., 2007. Penentuan kebutuhan pokok unsur hara $\mathrm{N}, \mathrm{P}, \mathrm{K}$ untuk pertumbuhan tanaman panili. Buletin Littro. Vol XVIII No.1, 4950.

SAS Institute, 2004, SAS Institute, Inc, Cary, North Carolina, USA.

Siswanto T., Sugiyanta, M. Melati, 2015. Peran Pupuk Organik dalam Peningkatan Efisiensi Pupuk an organik pada Padi Sawah. J Agron. Indonesia 43 (1) : 8-14

Suhartatik, E., Haryanto, \& Idawati. 2002. Serapan N padi sawah dan tanaman pupuk hijau (Sesbania rostrata) pada sistem tumpangsari. Hal. 140147 dalam Soejitno, J., Hermanto, Sunihardi (Eds.). Sistem Produksi Pertanian Ramah Lingkungan. Pusat Penelitian dan Pengembangan Tanaman Pangan. Bogor.

Tegoeh, W.H. 2016. Kajian Strategis Kebijakan Sistem Logistik Produk Kedelai di Jawa Tengah. Surakarta.

Wahyuni, S., 2014. Efektivitas pelapisan urea arang aktif yang diperkaya mikroba indegenus terhadap penurunan residu heksaklorobenzen dan endrin. (Tesis). Program Pasca sarjana. Universitas Sebelas Maret. Surakarta.

Wahyuni S., Paradifan, A. Kurnia, Indratin. 2018. Pengaruh pemberian Bacillus aryabhattai terhadap peningkatan populasi bakteri penambat $n$ simbiotik dan peningkatan produksi tanaman bawang daun. J Bappeda Jateng. Edisi Desember.

Park, Yeon-Gyeong. 2017. Bacillus aryabhattai SRB02 tolerates oxidative and nitrosative stress and promotes the growth of soybean by modulating the production of phytohormones. Korea. Plos One. 